\title{
Physiological Maturity of Parapiptadenia rigida Seeds
}

\author{
Hannah Braz ${ }^{1}$, Danieli Regina Klein ${ }^{1}$, Deise Cadorin Vitto ${ }^{1}$, Neri Ebeling ${ }^{1}$, Marlene Matos Malavasi ${ }^{1}$, \\ Ubirajara Contro Malavasi ${ }^{1}$, Maria Soraia Fortado Vera Cruz ${ }^{1}$, Ana Carolina Pingueli Ristau ${ }^{1}$, \\ Maria Eunice Lima Rocha ${ }^{1} \&$ Pablo Wenderson Ribeiro Coutinho ${ }^{1}$ \\ ${ }^{1}$ Department of Plant Production, State University of the West of Paraná, Marechal Cândido Rondon, Brazil \\ Correspondence: Hannah Braz, Department of Plant Production, State University of the West of Paraná, \\ Marechal Cândido Rondon, Brazil. E-mail: hannahbraz@hotmail.com
}

Received: March 20, 2018

doi:10.5539/jas.v10n10p485
Accepted: June 17, $2018 \quad$ Online Published: September 15, 2018

URL: https://doi.org/10.5539/jas.v10n10p485

\begin{abstract}
The establishment of appropriate standards related to the physiological and morphological aspects of the seeds are fundamental procedures to help the nurserymen and seed producers in determining the maturity and the appropriate moment of collection of the fruits. In this sense, the objective of this research is to evaluate the physiological maturation of seeds of Parapiptadenia rigida by means of germination and vigor tests, based on the color of the pods. The seeds were collected in June 2017, from three matrices located in the municipality of Marechal Cândido Rondon, Paraná, Brazil. The pods were classified in four stages of maturation, according to the Chart of colors model "Munsell colors chart" for plants tissues, and measured the biometric parameters. The parameters observed to evaluate the germinative potential are: first germination count, germination velocity index, emergency velocity index, and fresh and dry matter masses of seedlings. The experimental design was completely randomized, with five maturation stages and four replicates of 25 seeds each. The averages were compared using the Tukey test at a 5\% probability. The germination test showed that the increase in physiological potential of $\mathrm{P}$. rigida seeds is associated with the progresses of pod maturation. Therefore, the vigor test demonstrated that the physiological maturation of the species is simultaneous with the change of coloration and maturation of the pods.
\end{abstract}

Keywords: germination, vigor, maturation stage, native species

\section{Introduction}

The species Parapiptadenia rigida (Benth.) Brenan, belong to the Fabaceae family, this species is characteristic and exclusive of the Paraná, Uruguay and its tributaries river basins. Parapiptadenia rigida (Benth.) Brenan is recommended for the recovery of degraded areas and forest restoration in areas of permanent preservation. It is an early secondary tree, its wood is heavy, elastic and highly durable, which makes it suitable for rural constructions and for carpentry, besides its use for tanneries, because it is rich in tannin (Lorenzi, 2008).

The need for conservation of tropical forests and the strengthening of environmental policy promoted an increase in the demand for seeds of native species, which constitute a basic input in the ecosystem conservation programs (Carvalho, Silva, \& Davide, 2006). The knowledge of the morphological and ecophysiological characteristics of the seeds of native forest species, with a view to the production of seedlings, are important for the biodiversity conservation. Ferreira (2000) observed the lack of basic information about native species makes it difficult to use silvicultural programs, and the germ studies are fundamental for the knowledge of the anatomy, morphology and physiology of the seeds.

The objective of this study is to define the ideal harvest time and the highest quality of seed stage, known as physiological maturity (Popinigis, 1985), which varies according to species and environmental conditions. After this moment, the permanence of the seeds in the field results in their progressive deterioration (Lazarotto, 2011). This process results from morphological, physiological and functional changes, such as increase in size, variations in water content, vigor and accumulation of dry mass, that follow from the fertilization of the ovum until the moment when the seeds are ripe (Carvalho \& Nakagawa, 2012).

These modifications include a set of preparation steps for the germination process, essentially characterized by the synthesis and accumulation of reserves (Marcos-Filho, 2015). Figliolia and Kageyama (1994) explained that the knowledge of the physiological maturity point of seeds contributes to understanding the behavior of the species in terms of their reproduction, as well as the obtaining of good physiological quality genetic material, 
which is the fundamental basis for the programs silvicultural breeding, genetic conservation and recovery of degraded áreas.

The physiological quality of the seed is related to the capacity to perform its vital functions, characterized by its germination, vigor and longevity. Thus, the level of physiological quality of the seed is evaluated by two fundamental parameters: viability and vigor. The viability, measured by the germination test, determines the maximum germination of the seed, offering for this, the most favorable conditions possible. The vigor represents more subtle attributes of physiological quality, being determined in unfavorable conditions or evaluation of the decline of some biochemical or physiological function of the seed (Popinigis, 1985).

Seed vigor can be defined by Baalbaki, Elias, Marcos-Filho and Mcdonald (2009) as the properties that determine the potential for rapid and homogeneous emergence and the normal development of seedlings under varying environmental conditions. The evaluation of the vigor in the seeds of the forest species is a practice that allows us to estimate and to compare different objectives in many seeds (Valentini \& Piña-Rodrigues, 1995). Duarte and Carneiro (2009) claim that the harvesting point depends on the occurrence of the physiological maturity of the seed, which in many cases coincides with the maximum accumulation of dry matter and, when the seeds reach this point stage, generally it is potential for germination and vigor rises.

According to Piña-Rodrigues and Aguiar, (1993) the physiological maturation of the seeds can be detected by physical changes such as changes in color of the fruit, size, odor, dehiscence of fruit, among others. Several studies indicate the change in color of the fruit as a good indicator of physiological seed maturation, Allophylus edulis (Kaiser et al., 2016), Inga laurina (Schulz, Oro, Volkweis, Malavasi, \& Malavasi, 2014), Jatropha curcas (Rubio, Meneghel, Gomes, \& Malavasi, 2013; Dranski, et al., 2010), Machaerium brasiliense (Guimarães \& Barbosa, 2007).

It is of fundamental importance to determine adequate patterns related to the physiological and morphological aspect of the seed, as well as to define the maturation point and the appropriate time of fruit harvest, in order to help nurserymen and seed producers. Thus, the objective of the study was to evaluate, through germination and vigor tests, the physiological maturation of Parapiptadenia rigida seeds, based on the color of the pod.

\section{Materials and Methods}

\subsection{Collect and Classification Seeds}

The experiment was accomplished at the Seed Technology Laboratory of the State University of the West of Paraná (UNIOESTE), Campus Marechal Candido Rondon, using seeds of Parapiptadenia rigida.

The seeds were collected from three matrices located in Marechal Cândido Rondon, Paraná, Brazil. Claim to Köppen, the classification of this region climate is Cfa, mesothermic, humid subtropical (Alvares, et al., 2014), with hot summers (average temperature over $22{ }^{\circ} \mathrm{C}$ ) and winters with little frost (average temperature below 18 ${ }^{\circ} \mathrm{C}$ ) and an average annual rainfall of $1,500 \mathrm{~mm}$.

The collection was carried out directly in the trees, with the aid of pruning shears, composing a lot of pods, which were separated according to the degree of maturation, determined by the color difference. The pods were classified in four maturation stages according to the color chart, Munsell color charts for planttissues model (Munsell, 1976), in 7.5 GY 5/8, stage I: light green; 2.5 GY 6/10, stage II: dark green; 2.5 GY 5/4, stage III: light brown; 5 YR 3/2, stage IV: dark brown (Table 1). After sorting the pods, the seeds were benefited, being extracted manually, and then mixed and homogenized, constituting representative lots for each treatment. 
Table 1. Color of fruits of P. rígida in different maturation stages

\begin{tabular}{|c|c|c|c|}
\hline Maturation stage & Coloro of fruit & Visual Classification & Letter from Munsell \\
\hline I & & Light Green & 7.5 GY $5 / 8$ \\
\hline II & & Dark Green & 2.5 GY $6 / 10$ \\
\hline III & & Light Brown & 2.5 GY $5 / 4$ \\
\hline IV & & Dark Brown & 5 YR $3 / 2$ \\
\hline
\end{tabular}

\subsection{Biometric Parameters of Seeds}

The seeds were manually extracted and the biometric parameters length and diameter using a digital caliper were subsequently measured. The water content was determined by the oven method at $105 \pm 3{ }^{\circ} \mathrm{C}$, during 24 hours (MAPA, 2009), with 5 treatments, 4 replicates of 25 seeds each. The mass of one thousand seeds was calculated according to the RAS Seed Analysis Rule (MAPA, 2009).

\subsection{Germination Test}

The seeds were germinated using germitest paper, moistened with distilled water 2.5 times the value of their weight and packed in a germination chamber type BOD, with constant temperature of $25^{\circ} \mathrm{C}$ and photoperiod of 12 hours. Daily tally of normal and abnormal seedlings were performed, with criteria determined by the Rules for Seed Analysis (RSA) (MAPA, 2009). Subsequently, the percentage of germination, the average germination speed (AGS) and the mean germination time (MGT) were calculated. The calculation of the percentage of germination of AGS and MGT were performed according to Labouriau (1983):

$$
G(\%)=(\mathrm{N} / \mathrm{A}) \times 10
$$

Where, $\mathrm{G}$ is the percentage of germination; $\mathrm{N}$ is the number of germinated seeds (during 40 days); and $\mathrm{A}$ is the total number of seeds placed to germinate.

$$
\begin{gathered}
M G T(\text { days })=\left(\Sigma \mathrm{n}_{\mathrm{t}} \times \mathrm{ti}\right) /\left(\Sigma \mathrm{n}_{\text {total }}\right) \\
A G S\left(\text { days }^{-1}\right)=1 / \mathrm{t}
\end{gathered}
$$

Where, $M G T$ refers to the mean germination time in days; nt is the number of seeds germinated in a time interval; $t i$ is the time interval (40 days); $\mathrm{n}$ total is the total number of seeds germinated; $\mathrm{v}$ is the average speed of germination. 


\subsection{Vigor Test Based on Seedling Performance}

\subsubsection{Germination Speed Index}

$$
\mathrm{GSI}=(\mathrm{G} 1 / \mathrm{N} 1+\mathrm{G} 2 / \mathrm{N} 2+\mathrm{Gn} / \mathrm{Nn})
$$

Where, $\mathrm{GSI}=$ germination velocity index; $\mathrm{G}=$ number of seeds germinated; $\mathrm{N}=$ number of days of sowing.

\subsubsection{Emergency Velocity Index}

It was accomplished in a greenhouse, on what the seeds were sown in trays containing commercial substrate, and the number of emerged seedlings with above ground tisues was recorded daily until emergency stabilization, and this was calculated by the formula proposed by Maguire (1962):

$$
\mathrm{ESI}=(\mathrm{E} 1 / \mathrm{N} 1+\mathrm{E} 2 / \mathrm{N} 2+\mathrm{En} / \mathrm{Nn})
$$

Where, ESI = emergency speed index. E1, E2, En = number of normal seedlings computed in the first count, the second count and the last count. N1, N2, Nn = number of days of sowing at the first, second and last count.

\subsubsection{First Germination Count}

The first germination count was performed in conjunction with the germination test, for which the percentage of normal seedlings was counted on the fifth day after the test installation (MAPA, 2013).

\subsubsection{Masses of Fresh and Dry Weight of Seedlings}

At the end of germination and emergency test, seedlings were weighed in scales were weighed in an analytical balance with an accuracy of $0.0001 \mathrm{~g}$, to obtain fresh matter mass (FMM). After they were packed in kraft paper bags and placed in a drying oven at $60 \pm 2{ }^{\circ} \mathrm{C}$ for $72 \mathrm{~h}$, to measure the dry wight mass of seedlings (DWM).

\subsection{Statistical Analysis}

The experimental design was completely randomized, with 4 maturation stages, 5 replicates of 25 seeds each.

The results were verified for normality and homogeneity and submitted to analysis of variance ( $\mathrm{F}$ test). When appropriated, means were compared by Tukey test at $5 \%$ of probability.

\section{Results and Discussion}

\subsection{Seed Characterization}

There was a significant difference to longitudinal diameter seed (LDS), transverse diameter seed (TDS) thousand seed weight (TSW), misture content (MC), thickness (T) and dry weight mass (DWM) between the treatments (table 2).

Table 2. Biometric characterization of P. rígida seeds at different stages of the false fruit maturation

\begin{tabular}{llllll}
\hline Stage of maturation & LDS $(\mathrm{mm})$ & TDS $(\mathrm{mm})$ & T $(\mathrm{mm})$ & MC $(\%)$ & TSW \\
\hline $7.5 \mathrm{GY} \mathrm{5/8}$ & $12.73 \mathrm{~b}$ & $8.94 \mathrm{a}$ & $0.97 \mathrm{a}$ & $22.73 \mathrm{a}$ & $56.36 \mathrm{a}$ \\
$2.5 \mathrm{GY} \mathrm{6/10}$ & $13.60 \mathrm{a}$ & $9.17 \mathrm{a}$ & $0.64 \mathrm{~b}$ & $18.51 \mathrm{~b}$ & $43.81 \mathrm{~b}$ \\
$2.5 \mathrm{GY} \mathrm{5/4}$ & $12.78 \mathrm{~b}$ & $8.70 \mathrm{a}$ & $0.54 \mathrm{c}$ & $14.28 \mathrm{~b}$ & $40.33 \mathrm{~b}$ \\
$5 \mathrm{YR} \mathrm{3/2}$ & $13.05 \mathrm{ab}$ & $9.17 \mathrm{a}$ & $0.60 \mathrm{bc}$ & $9.87 \mathrm{c}$ & $31.52 \mathrm{c}$ \\
\hline CV\% & 4.82 & 5.51 & 7.43 & 10.43 & 7.8 \\
\hline
\end{tabular}

Note. $\mathrm{LDS}=$ longitudinal diameter seed, $\mathrm{TDS}=$ tranversal diameter seed, $\mathrm{T}=$ thickness, $\mathrm{MC}=$ misture conteint, thousand seed weight (TSW). * Means followed by the same letter in the columns do not differ by Tukey test (p $\leq 0.05)$.

The seeds of maturation stages II and IV showed higher averages. However, didn't occur significant difference between maturation stages for DTS variable. In terms of the variables T, MC and TSW, verified higher averages for the maturation stage I, $7.5 \mathrm{GY} 5 / 8$, as well as progressive reduction for the other stadiums. It can be inferred, through these results, that the seeds of Paraptadenia rigida, in the maturation stages evaluated, underwent dehydration concomitant to the advance of the stage of maturation of the pod, culminating in the reduction of the thickness and the water content of the seed. The morphometric data obtained in the study were similar to that measured by Gasparin (2012), and Marangoni Muniz, Binotto, Georgin, and Maciel (2014) for rigid Parapiptadenia rigida. 
The results observed for the biometric data of $P$. rigida show that the seeds were harvested when they had reached the point of physiological maturity, because no differences were observed between the stages of maturation for the transverse diameter of the seed. It can be deduced that these had already reached the maximum size, in addition they were verified reductions of the moisture content of the seeds, process that occurs naturally and concomitant to the maturation of the seeds.

Therefore, it is possible to infer that the variations observed for the other morphological characteristics of the seeds of the different stages of maturation are related to the loss of water observed according to the degree of maturation of the same. In this sense, Marcos-Filho (2015) explains that during the development period, the maturation of the seeds go through a series of modifications, among them morphological changes, where the seeds need a high water content for partition of solutes until reaching the maximum accumulation of dry matter, coinciding with the point of physiological maturation, at this moment, the author states that there is the disconnection of these seeds from the mother plant, followed by intense dehydration of the seeds.

\subsection{Germination Test}

Differences $(\mathrm{p} \leq 0.05)$ were detected for germination percentage $(\mathrm{G} \%)$, germination speed index (GSI), mean germination time (MGT) and average germination speed (AGS), as a function of seed maturation stage (Table 3).

Table 3. Germination parameters of $P$. rigida seeds at different maturation stages of false fruit maturation

\begin{tabular}{llll}
\hline Maturation stages & G\% & MGT (days) & AGS (days $\left.{ }^{-1}\right)$ \\
\hline 7.5 GY 5/8 & $4.00 \mathrm{c}$ & $4.60 \mathrm{~b}$ & $0.080 \mathrm{c}$ \\
$2.5 \mathrm{GY} \mathrm{6/10}$ & $55.00 \mathrm{~b}$ & $7.69 \mathrm{a}$ & $0.130 \mathrm{~b}$ \\
$2.5 \mathrm{GY} \mathrm{5/4}$ & $68.00 \mathrm{a}$ & $4.84 \mathrm{~b}$ & $0.214 \mathrm{a}$ \\
$5 \mathrm{YR} \mathrm{3/2}$ & $63.75 \mathrm{a}$ & $4.67 \mathrm{~b}$ & $0.218 \mathrm{a}$ \\
\hline CV\% & 5.43 & 5.97 & 9.65 \\
\hline
\end{tabular}

Note. $\mathrm{G} \%=$ Percentage of germination, MGT = mean germination time, AGS = average germination speed. * Means followed by the same letter in the columns do not differ by Tukey test $(\mathrm{p} \leq 0.05)$.

Seeds of the 2.5 GY $5 / 4$ and 5 YR 3/2 stages showed the highest percentage of germination $(68.0 \%$ and $63.75 \%$, respectively), as well as lower MGT and higher GSI. There was a drastic reduction in the G\% for stage I, however, at this stage a high water content was also observed for the seeds, suggesting that although these seeds have already reached physiological maturation, they are still low potential for harvesting. The lower average MGT observed in stage it is related to the low percentage of germinated seeds, therefore, it is not referred as indicative of high potential.

The results indicate that there is an increase in the physiological potential of $P$. rigida seeds as the pod maturation stage is advanced. In addition, it can be suggested that the maximum physiological potential of $P$. rigida seeds was obtained at the stage of maturation III and remained at the next stage studied (stage IV), according to Marcos-Filho (2015). Since the seed reaches the maximum physiological potential, it can only be maintained or decreased, so this point is considered the physiological peak, and also the initial mark of seed deterioration.

Several studies, carried out with several species, indicate differences in the germination potential of the seeds as a function of the maturation stage of the fruits, for example Machaerium brasiliense V. (Guimarães \& Barbosa, 2007), Jatrophacurcas L. (Dranski et al., 2010), Cedrela fissilis (Ristau et al., 2017), Hovenia dulcis T. (Vera Cruz et al., 2017).

\subsection{Vigor Test}

Table 4 shows the averages for first germination count (FGC), germination speed index (GSI), emergence speed index (ESI), fresh matter mass (FMM) and dry matter mass (DMM) of Paraptadenia rigida seedlings. 
Table 4. Averages of germination test of $P$. rigida seeds in differents maturation stages

\begin{tabular}{llllll}
\hline Maturation stages & FGC $(\%)$ & GSI & ESI & FMM $(\mathrm{g})$ & DMM $(\mathrm{g})$ \\
\hline $7.5 \mathrm{GY} \mathrm{5/8}$ & $1.00 \mathrm{c}$ & $0.138 \mathrm{c}$ & $0.230 \mathrm{c}$ & $1.93 \mathrm{~b}$ & $0.25 \mathrm{~b}$ \\
$2.5 \mathrm{GY} \mathrm{6/10}$ & $7.00 \mathrm{~b}$ & $1.806 \mathrm{~b}$ & $1.264 \mathrm{~b}$ & $2.04 \mathrm{~b}$ & $0.35 \mathrm{~b}$ \\
$2.5 \mathrm{GY} \mathrm{5/4}$ & $6.67 \mathrm{~b}$ & $3.238 \mathrm{a}$ & $3.624 \mathrm{a}$ & $2.53 \mathrm{a}$ & $0.57 \mathrm{a}$ \\
$5 \mathrm{YR} 3 / 2$ & $8.75 \mathrm{a}$ & $3.432 \mathrm{a}$ & $4.046 \mathrm{a}$ & $2.25 \mathrm{a}$ & $0.63 \mathrm{a}$ \\
\hline CV $\%$ & 5.85 & 10.94 & 11.5 & 12.83 & 4.65 \\
\hline
\end{tabular}

Note. First germination count $=$ FG, germination speed index $=$ GSI, emergency speed índex $=$ ESI, fresh matter mass $=\mathrm{DMM}$, dry matter mass $=\mathrm{DMM} *$ Means followed by the same letter in the columns do not differ by Tukey test $(\mathrm{p} \leq 0.05)$.

The first germination count test indicated a progressive increase in the meantime concomitant to the advancement of pod maturation stages, where the highest percentage of germinated seeds at the first count was observed at the maturation stage IV (5 YR 3/2). For the GSI and ESI parameters, the highest indices were obtained in maturation stages III and IV.

The results obtained corroborate Berloffa, Graichen, Fernandes, and Silva (2015), where they evaluated the physiological quality of seeds of the same species under different conditions and verified that the highest averages were observed for the dark brown seeds fixed in the plant. Contrary results were observed by Sobral, Brunetto, Belotti, and Batassare (2010), where they verified a reduction in the germination and emergence of $P$. rigida seeds in the last weeks of collection, in which the pods were dark brown.

Seeds belonging to the stages with light brown and dark brown pods presented higher masses of fresh matter and dry matter of seedlings, and it can be inferred that the data obtained are indicative of greater vigor. In this sense, Dan, Mello, Wetzel, Popinigis, and Zonta (1987) affirm that vigorous seeds originate seedlings with higher growth rates due to the greater capacity of transformation and supply of storage reserves and the greater incorporation of these by the embryonic axis. In addition, Marcos Filho (2015) explained that the changes in seed vigor is related to increase dry matter transfer from the adult plant to the seeds, so that the proportion of vigorous seeds increases with maturation.

The results for the vigor tests corroborate with a hypothesis that is a physiological maturation of the seeds of Paraptadenia rigida is simultaneous to the change of heart and maturation of the pods, as it is observed an increase in the means, for all tests of seed vigor, according to the increase in pod maturation levels.

\section{Conclusion}

The maturation stage exert different results on germination and vigor of seeds. The biometric characteristics, germination and vigor test are parameters that indicate the potentiality and physiological maturity of the seeds of P. rigida, for the reason that allowed us to discern that there was an increase in the physiological potential concomitant to the progress of the maturation stage.

The seeds of $P$. rigida belonging to fruits (pod) of light brown to dark brown coloring, still fixed at adult plant, presented better performance as regards viability and vigor when compared to seeds from fruits with greenish coloration.

\section{References}

Alvares, C. A., Stape, J. L., Sentelhas, P. C., Moraes, G., Leonardo, J., \& Sparovek, G. (2014). Köppen’s climate classification map for Brazil. Meteorologische Zeitschrift, 22(6), 711-728. https://doi.org/10.1127/ 0941-2948/2013/0507

Baalbaki, R., Elias, S., Marcos-Filho, J., \& Mcdonald, M. B. (2009). Seed vigor testing handbook. Ithaca: Association of Official Seed Analysts.

Berloffa, J. M., Graichen, F. A. S., Fernandes, F. M., \& Silva, A. R. D. (2015). Qualidade fisiológica e sanitária de sementes de angico-vermelho sobre o crescimento inicial de plântulas. Revista de Ciências Agroambientais, 13(2), 78-86.

Carvalho, L. R. E., Silva, A. A., \& Davide, A. C. (2006). Classificação de sementes florestais quanto ao comportamento no armazenamento. Revista Brasileira de Sementes, 28(2), 15-25. https://doi.org/10.1590/ S0101-31222006000200003

Carvalho, N. M., \& Nakagawa, J. (2012). Sementes: Ciência, tecnologia e produção. Jaboticabal, SP: FUNEP. 
Dan, E. L., Mello, V. D. C., Wentzel, C. T., Popinigis, F., \& Zonta, E. P. (1987). Transferência de matéria seca como método de avaliação de vigor de sementes de soja. Revista Brasileira de Sementes, 9(3), 45-55.

Dranski, J. A. L., Pinto Júnior, A. S., Steiner, F., Zoz, T., Malavasi, U. C., Malavasi, M. M., \& Guimarães, V. F. (2010). Physiological maturity of seeds and colorimetry of fruits of Jatrophacurcas L. Revista Brasileira de Sementes, 32(4), 158-165.https://doi.org/10.1590/S0101-31222010000400018

Duarte, E. F., \& Carneiro, I. F. (2009). Qualidade fisiológica de sementes de Dyckiagoehringii Gross \&Rauh (bromeliaceae) em função do estádio de maturação dos frutos. Bio Science Journal, 25(3), 161-171.

Ferreira, C. A. C. (2000). Recuperação de áreas degradadas. Informe Agropecuário, 21(202), 127-130.

Figliolia, M. B., \& Kageyama, P. Y. (1994). Maturação de sementes de IngauruguensisHook et Arn em floresta ripária do rio Moji Guaçu, Município de Moji Guaçu, SP. Revista do Instituto Florestal, 6(Único), 13-52.

Gasparin, E. (2012). Armazenamento de sementes e produção de mudas de Parapiptadeniarigida (Benth.) Brenan (146f, Dissertação Mestrado em Engenharia Florestal, Universidade Federal de Santa Maria, Santa Maria, Rio Grande do Sul).

Guimarães, D. M., \& Barbosa, J. M. (2007). Coloração dos Frutos como Índice de Maturação para Sementes de Machaerium brasiliense Vogel (Leguminosae-Fabaceae). Revista Brasileira de Biociências, 5(2), 567-569.

Kaiser, D. K., Malavasi, M. M., Malavasi, U. B., Dranski, J. A. L., Freitas, L. C. N., Kosmann, C. R., \& Andrioli, K. K. (2016). Physiological maturity of seeds and colorimetry of the fruits of Allophylus edulis [(A. St.-Hil., A. Juss. \& Cambess.) Hieron. ex Niederl.]. Journal of Seed Science, 38(2), 092-100. https://doi.org/ 10.1590/2317-1545v38n1154590.

Labouriau, L. G. A. (1983). Germinação de sementes. Washington, DC: OEA.

Lazarotto, M., Beltrame, R., Muniz, M. F. B., \& Blume, E. (2011). Maturação fisiológica de sementes de Erythrina crista-galli L. Ciência Florestal, 21(1), 9-16. https://doi.org/10.5902/198050982742

Lorenzi, H. (2008). Árvores brasileiras: Manual de identificação, cultivo de plantas arbóreas nativas do Brasil (5th ed.). Nova Odessa: Plantarum.

Maguire, J. D. (1962). Speed of germination aid in selection and evaluation for seeding emergence and vigor. Crop Science, 2(2), 176-177. https://doi.org/10.2135/cropsci1962.0011183X000200020033x

MAPA (Ministério da Agricultura Pecuária e Abastecimento). (2009). Regras para análise de sementes. Brasília, DF: Ministério da Agricultura Pecuária e Abastecimento.

MAPA (Ministério da Agricultura Pecuária e Abastecimento). (2013). Instruções para análise de sementes de espécies florestais. Brasília, DF: Ministério da Agricultura Pecuária e Abastecimento.

Marangoni, L. D., Muniz, M. F. B., Binotto, R., Georgin, J., \& Maciel, C. G. (2014). Influência do teor de umidade na germinação de sementes de Parapiptadenia rigida (BENTH.) Brenan. Pesquisas Agrárias e Ambientais, 02(04), 224-228. https://doi.org/10.14583/2318-7670.v02n04a07

Marcos-Filho, J. (2015). Fisiologia de sementes de plantas cultivadas (2nd ed.). Londrina, PR: Abrates.

Munsell, A. H. (1976). Munsell book of color. Baltimore: Macbeth Vivision of Kollmorgen.

Oro, P., Schulz, D. G., Volkweis, C. R., Bandeira, K. B., Malavasi, U. C., \& Malavasi, M. M. (2012). Maturação fisiológica de sementes de Eugenia pyriformis Cambess e Eugenia involucrata DC. Biotemas, 25(3), 11-18. https://doi.org/10.5007/2175-7925.2012v25n3p11

Piña-Rodrigues, F. C. M., \& Aguiar, I. B. (1993). Maturação e dispersão de sementes. In I. B. Aguiar, F. C. M. Piña-Rodrigues, \& M. B. Figliolia (Eds.), Sementes florestais tropicais. Brasília: ABRATES.

Popinigis, F. (1985). Fisiologia da semente (2nd ed.). Brasília, DF: ABRATES.

Ristau, A. C. P., Vera Cruz, M. S., Rocha, M. E. L., Braz, H., Abade, M. T. R., \& Malavasi, M. M. (2017). Physiological maturity of seeds of Cedrela fissilis. IOSR Journal of Agriculture and Veterinary Science, 10(10), 09-12. https://doi.org/10.9790/2380-1010010912

Rubio, F., Meneghel, A. P., Gomes, L. F. S., \& Malavasi, M. M. (2013). Estádios de maturação do fruto no desempenho germinativo e teor de óleo de sementes de Jatrophacurcas Linn. Semina: Ciências Agrárias, 34(2), 663-668. https://doi.org/10.5433/1679-0359.2013v34n2p663 
Schulz, D. G., Oro, P., Volkweis, C., Malavasi, M. M., \& Malavasi, U. C. (2014). Maturidade fisiológica e morfometria de Sementes de ingalaurina (Sw.) Willd. Floresta e Ambiente, 21(1), 45-51. https://doi.org/ 10.4322/floram.2014.007

Sobral, L. S., Brunetto, R. S., Belotti, A., \& Batassare, A. M. (2010). Maturação fisiológica de sementes de angico-vermelho [Parapiptadenia rigida (Benth.) Brenan]-Fabaceae. Unochapeco, 5(1), 75-81.

Valentini, S. R. T., \& Piña-Rodrigues, F. C. (1995). Aplicaçãodo teste de vigor em sementes (pp. 75-84). São Paulo: [s.n.].

Vera Cruz, M. S. F., Rocha, M. E. L., Ristau, A. C. P., Coutinho, P. W. R., Malavasi, M. M., Malavasi, U. C., ... Ebeling, N. (2017). Hovenia dulcisT. fruit colorimetry for determination of physiological maturity of seeds. Journal of Agricultural Science, 10(1), 293-301. https://doi.org/10.5539/jas.v10n1p293

\section{Copyrights}

Copyright for this article is retained by the author (s), with first publication rights granted to the journal.

This is an open-access article distributed under the terms and conditions of the Creative Commons Attribution license (http://creativecommons.org/licenses/by/4.0/). 